\title{
Ana Cristina Cesar e Paulo Leminski trocam cartas
}

Joacy Ghizzi Neto

UFSC

\section{Resumo}

O texto a seguir tem como objeto as poéticas de Ana Cristina Cesar e Paulo Leminski, mais precisamente no que tocam uma "retórica da correspondência”. O trabalho propõe uma aproximação entre dois poetas emblemáticos das décadas de 70 e 80 (os únicos com correspondências publicadas) na perspectiva da interlocução e interpelação do outro que suas poéticas sugerem. Para tal leitura, foram trabalhados textos de Flora Süssekind, Marcos Siscar e Silviano Santiago, que exploram estas questões na poética de Ana C., além do referencial teórico de Jacques Lacan ("O seminário sobre a carta roubada”) e Jaques Derrida ( $O$ cartão-postal), e ainda o referencial de David Wellbery acerca da retoricidade e do endereçamento.

Palavras-chave: Ana Cristina Cesar; Paulo Leminski; correspondência; endereçamento; retoricidade.

\begin{abstract}
The following text centres upon the poetic of Ana Cristina Cesar and Paulo Leminski, more precisely it touches on their "rhetoric of correspondence". The article proposes an approach between the two emblematic poets of the 70s and 80 s (only those that have some published correspondence) from the perspective of the interlocution and the interpellation of the other that their poetics suggest. This reading drew upon works from Flora Süssekind, Marcos Siscar and Silviano Santiago which explore these issues in the poetics of Ana C., alongside the theories of Jacques Lacan ( $\mathrm{O}$ seminário sobre 'A carta roubada”') and Jacques Derrida ( $O$ cartão-postal), as well as the referential from David Welberry about rhetoricity and addressing.
\end{abstract}

Keywords: Ana Cristina Cesar; Paulo Leminski; correspondence; addressing; rhetoricity. 
1. Ana Cristina Cesar, apud: SISCAR, Marcos. “Apresentação", 2012, p.11.

2. SISCAR, Marcos.

“Apresentação”, 2012, p.9

3. Ibidem, p.12. Grifo meu.

4. Outras publicações de correspondências da mesma época que merecem destaque: Cartas (1964-1974) de Lygia Clark e Hélio Oiticica, Cartas de Caio Fernando Abreu e Cartas ao mundo de Glauber Rocha.

5. SISCAR, Marcos. “Apresentação”, 2012, p. 12.

6. Régis Bonvicino, destinatário da correspondência publicada, afirma que as cartas diminuíram consideravelmente depois que Leminski (Uma carta uma brasa através, 1992, p.14) comprou seu primeiro telefone em 1981 ; destaque-se ainda o relato de Toninho Vaz na biografia $O$ bandido que sabia latim (2005, p.227), sobre a "pequena fortuna" das contas de telefone de Leminski. quem não tem senso de humor nunca vai entender a piada Paulo Leminski

No texto de "Apresentação" ao livro de poemas de Ana Cristina Cesar, que faz parte da coleção Ciranda da Poesia da Editora UERJ, Marcos Siscar resgata uma comunicação de Ana Cristina Cesar em um curso universitário nos anos 80, na qual a poeta encerrou o debate pedindo para que o público de então lhe escrevesse cartas. "Vocês me escrevam cartas do que vocês acharam, assim: 'Prezada autora'. Ah, eu quero receber cartas". ${ }^{1}$ Seguindo a própria ideia de que apresentar a obra de algum escritor seria "apresentar uma cena, sua relação com outros textos, de natureza diversa, suas formulações, suas interpretações [...]"2, Siscar desdobra em seu texto uma outra cena, que é seu próprio texto, que seria então a carta que Ana Cristina Cesar havia pedido ao seu público: "Escrever essa carta para Ana C. seria uma forma de devolver o poema [...]”3.

O presente texto tem então como tarefa propor também outra cena: que Ana C. e Paulo Leminski troquem cartas. Ou seja, que justamente dois poetas-críticos-tradutores das décadas de 70 e 80 , que possuem parte de suas correspondências já publicadas ${ }^{4}$ - em mais um indício dos seus processos de consagração - possam estabelecer um contato, na verdade um atrito, que aparentemente não aconteceu em vida ou em texto de forma "direta”. Até o momento desconheço qualquer aproximação entre os dois poetas da forma como tiveram Leminski com Waly Salomão e Ana Cristina Cesar com Armando Freitas Filhos, por exemplo. Entretanto, é justamente necessário estabelecer em e entre ambos aquilo que Siscar reconheceu em Ana C: “[...] notória a referência à retórica da correspondência, dos cartões postais e mesmo do diário, que segundo ela, são gêneros ligados à destinação, ainda que o destinatário permaneça indeterminado". 5

Não são somente as próprias correspondências que evidenciam a relação dos dois com essa prática milenar já em vias de extinção na própria época dos poetas - devido ao surgimento do telefone e telefax ${ }^{6}$ - mas os traços que essa experiência epistolar marcou em via de mão dupla na própria poética de Ana C. e Leminski. Ou seja, trata-se de investigar para além da prática epistolar como "oficina” de criação dos poetas, ou como lugar de retorno da paternidade do autor na explicação da própria obra, mas como possibilidade de investigar as marcas que o jogo da correspondência deixou nas suas próprias práticas literárias, passando constantemente pela questão do endereçamento.

$\mathrm{Na}$ cena que monta, Siscar propõe um acerto de contas 
entre Ana C. e João Cabral de Melo Neto, a fim de mostrar que apesar da afirmação da própria poeta, que sua geração seria marcada pelo "traço anticabralino", os dois não diferem quanto às suas concepções de poesia. Ou seja, que suas "teorias do poema" seriam a mesma quanto à "superação da relação ingênua entre linguagem e realidade". ${ }^{8}$ A parte racional do rigor na poesia de João Cabral, via sua conferência Poesia e composição (1952), estaria subordinada a "acionar aqueles elementos que fazem parte da expectativa do leitor". Assim, além de rejeitar a ideia do poema como intermediário entre a realidade e a poesia, ideia fundamental da poesia moderna que Leminski reformulara afirmando que "Ele [o poema de invenção ou experimental] é um novo objeto do mundo" ${ }^{10}$, Cabral já estaria também preocupado com uma ética poética da destinação, ou seja, da relação que a poesia estabelece com o outro, com seu leitor.

Siscar resgata então o debate entre Lacan ("O Seminário sobre 'A carta roubada"” ${ }^{11}$ ) e a leitura de Derrida ("O carteiro da verdade" ${ }^{12}$ ) e a potência do significante letter que, assim como no inglês e no francês (lettre), significa tanto letra quanto carta. Línguas que Ana C. e Leminski trans(it)aram em suas traduções. Ou seja, o problema da letra, da literatura, passa sempre por uma questão que é tanto da correspondência, "remetente x destinatário", quanto da poesia, "poeta x leitor”. No Seminário, Lacan defende que é a manutenção da materialidade do significante letter, a despeito do seu desvio de percurso, que garante que a carta seja, no conto de Poe, "o verdadeiro sujeito do conto: é por poder sofrer um desvio que ela tem um trajeto que lhe é próprio"13. Mas, diante do desvio do percurso, Lacan nos brinda uma pergunta fundamental acerca das questões da correspondência: "Para que haja carta roubada, diremos conosco, a quem pertence uma carta/letra?"14 Questionado o valor de pertencimento e posse de uma carta, já que segundo Josefina Ludmer "não se sabe de quem é a carta, se daquele que a escreveu, disse eu e citou o outro, ou de quem a recebe e a exibe, de quem lê eu" "15, Lacan parte então para o desdobramento da questão anterior: "Então, a carta/letra sobre a qual quem a enviou ainda conserva direitos não pertenceria plenamente àquele a quem se dirige? Ou será que este último nunca foi seu verdadeiro destinatário?"16

Assim, as figuras do remetente e destinatário não são mais papéis fixos e pré-estabelecidos, garantidos pela assinatura de quem escreve, mas figuras ambivalentes que possuem uma relação de oscilação e dependência recíproca. Ao revisitar a tradição do haicai no poema a seguir, Leminski nos coloca o dilema:
7. CESAR, Ana Cristina. Apud: MORICONI, Italo. Ana Cristina Cesar: o sangue de uma poeta, 1996, p.17.

8. SISCAR, Marcos, “Apresentação", 2012, p.17.

9. Ibidem, p. 20.

10. LEMINSKI, Paulo. Arte reflexo. In: Ensaios e anseios crípticos, 2011, p. 99.

11. LACAN, Jacques. Escritos, 1998. "O seminário sobre 'A carta roubada" é proferido para analistas em 1956, publicado em 1957 e em 1966 ganhará lugar de emblemática abertura na reunião dos Ecrits do psicanalista francês.

12. DERRIDA, Jacques. O cartão-postal. De Sócrates a Freud e além, 2007. No original "Le facteur de la verité", que permite também a tradução "O fator da verdade".

13. LACAN, Jacques. "O seminário sobre 'A carta roubada”'. Escritos, 1998, p.33.

14. Ibidem, p. 30.

15. Cf. LUDMER, Josefina. "La novia (carta) robada (a Faulkner)". Disponível em www.cartas.org.ar/lecturas/leclud-lan.html, último acesso em 18/06/2013. Trecho com minha tradução.

16. LACAN, Jacques, Escritos, 1998, p. 30. 
17. LEMINSKI, Paulo.

Distraídos venceremos. $5^{\circ} \mathrm{ed}$. São Paulo: Brasiliense. p.117. Grifo meu.

18.LACAN, Jacques. Escritos, 1998, p. 45.

19. LEMINSKI, Paulo.

Caprichos \& relaxos. In: Toda poesia, 2013, p. 50.

20. CESAR, Ana Cristina. $A$ teus pés, 2002, p. 132.

21. FOUCAULT, Michel. A escrita de si. In: O que é um autor?, 1992.

22. Jacques Lacan apud. DERRIDA, Jacques. O cartãopostal, 2007, p. 468. choveu

na carta que você mandou quem mandou? ${ }^{17}$

É a partir da intervenção de uma "força natural" - e do gesto de rasura do poeta - que a ideia de autor e sua garantia pela assinatura ficam abaladas neste haicai que abre margem para uma zona de indecidibilidade entre duas figuras até então convencionais: o remetente e o destinatário. A garantia do percurso da correspondência também já não é mais infalível, e se "uma carta sempre chega a seu destino"18, o caminho é longo e tortuoso:
uma carta uma brasa através por dentro do texto nuvem cheia da minha chuva cruza o deserto por mim a montanha caminha o mar entre os dois uma sílaba um soluço um sim um não um ai sinais dizendo nós quando não estamos mais ${ }^{19}$

Neste poema, parece que a carta está a todo o momento prestes a desaparecer, e consequentemente sua mensagem/ conteúdo, ou ainda prestes a não cumprir seu percurso e destino. Uma carta/brasa, uma nuvem cheia que precisa cruzar um deserto, uma montanha que caminha e todos estes "sinais dizendo nós" estão marcados dentro dos próprios versos do poema por intervalos - por espaços maiores que o normal entre as palavras - que parecem evidenciar as intermitências de todo episódio de correspondência. Intermitência que Ana C. em Luvas de Pelica transformou na própria lógica do desejo da correspondência: "A única coisa que me interessa no momento é a lenta cumplicidade da correspondência. Leio para mim as cartas que vou mandar" ${ }^{20}$, evidenciando assim ainda a relação que a correspondência estabelece justamente com a escrita de $s i$, relação discutida por Foucault a partir da máxima de Sêneca: "assim como ouvimos o que dizemos, escrevemos lendo"21.

Ao ler o seminário de Lacan, Jacques Derrida irá detectar na leitura do psicanalista "a preeminência do significante sobre o sujeito" e "a supremacia do significante do sujeito"22, e dessa forma a figura do autor passa a ter papel secundário no sentido que o próprio sentido da correspondência não lhe é mais garantido, nem como direção, nem como conteúdo. $\mathrm{O}$ autor não comanda nem orienta a correspondência e é aquele que a detém posteriormente que passa a exercer o poder da posse, independentemente da mensagem que ela carrega: "a carta 
segue suas peripécias sem ela”, posição de Lacan no Seminário e mantida quinze anos depois em Lituratera (1971). Ainda acerca da mensagem da carta, uma de Leminski para Antonio Risério, de 1975, encontrada em sua biografia, começa com a figura fraterna do "Companheiro", traduzindo um termo tradicional da militância política para o da militância poética, e se despede da seguinte forma:

[...] detesto toda forma artificial de contato/comunicação (tipo carta, telefonema, telex, xerox), mas isto não é uma mensagem, é uma tangência uma coincidência um atrito e sobretudo um abraço do/ Leminski ${ }^{23}$

Leminski evidencia assim, como nos dois poemas anteriores, uma espécie de ceticismo e desconfiança da prática epistolar em meio sua própria execução. É interessante notar que o poeta descarta a possibilidade da carta carregar uma mensagem, mas ainda é capaz de mandar um abraço, um atrito. É segundo uma lógica do desejo, que Jean-Luc Nancy evidenciara como jeu (jogo) no lugar do je (eu $)^{24}$, que se arma o jogo da correspondência em Leminski e Ana Cristina Cesar. Na sessão de depoimentos dos destinatários que figuram na edição das cartas de Ana C., Correspondência Incompleta, Ana Candida Perez nos diz o seguinte: nossa troca de correspondências foi em parte uma experiência com a escritura - em uma das cartas Ana Cristina sugere que publicássemos as cartas como um texto de ficção. ${ }^{25}$

Texto epistolar de ficção que, segundo Liliana Heer em "La Correspondencia: Una Voz en el Camino", fora praticado por Luisa Valenzuela e Bolek Greczynski, entre Buenos Aires $\mathrm{x}$ Nova York, respectivamente, a partir de uma "correspondência ficcional” na qual criavam um "personagem imaginário”, chamado de Bonzo ou Gato. Em 1979 "ana cristina c.” realiza sozinha o projeto ficcional, cria personagens e escreve uma carta só, intitulada Correspondência Completa ${ }^{26}$ - frustrando qualquer expectativa do fetiche do leitor de "obras completas", com direito a rascunhos, diários, notas e cartas - criando uma espécie de diário que, segundo Habermas indagando o papel epistolar do século XVIII, "se torna uma carta destinada ao remetente" ${ }^{27}$. A carta em questão, assinada "Júlia" e destinada a "My Dear", é analisada por Silviano Santiago em "Singular e anônimo". Neste breve e belo ensaio, ao resgatar o "equívoco de Cacaso", poeta que afirmou que "o leitor está excluído" de determinado poema de Ana C., Silviano afirma justamente o contrário no início do texto: "a linguagem poética existe em estado de contínua travessia para o Outro. Ela nomeia o leitor" ${ }^{28}$. Sendo assim, o poema - e a poética de Ana C. - "não é um discurso em praça pública nem conversa a dois”, mas uma
23. Paulo Leminski, apud. VAZ, Toninho. Apêndices. Paulo Leminski: o bandido que sabia latim, 2005, p. 356. Grifo meu.

24. NANCY, Jean-Luc; LACOUE-LABARTHE, Philippe. O título da letra, 1991, p. 80.

\section{Ana Candida Perez} apud. CESAR, Ana Cristina. Correspondência incompleta, 1999, p. 302.

26.CESAR, Ana Cristina.

Correspondência completa. In: A teus pés, 2002, p. 115-121.

27. Jürgen Habermas apud. ARFUCH, Leonor. O espaço biográfico: dilemas da subjetividade contemporânea, 2002, p. 45.

28.SANTIAGO, Silviano. Singular e anônimo, 2000, p. 61. 
29. Ibidem.

30. CESAR, Ana Cristina, A teus pés, 2002, p. 63.

31. FREITAS, Armando, Filho. Jogo de cartas. In: CESAR, Ana Cristina. Correspondência incompleta, 1999, p. 9.

32. CESAR, Ana Cristina, Correspondência incompleta, 1999, p. 40.

33. CESAR, Ana Cristina.

Correspondência completa. $A$ teus pés, 2002, p. 121.

34. Heloísa Buarque de Hollanda. In: CESAR, Ana Cristina. Correspondência incompleta, p. 299.

35. LEMINSKI, Paulo. Ensaios e anseios crípticos, 2011, p. 127.

36. Ibidem. abertura para o "desconhecido e o obstáculo" 29 . Em um poema de Ana C. o jogo entre "completo e incompleto" da obra e a abertura do poema se arma mais uma vez:

Quando entre nós só havia
uma carta certa
a correspondência
completa
o trem os trilhos
a janela aberta
$[\ldots . .]^{30}$

A janela aberta aponta novamente para a questão da interlocução e da interpelação na "retórica da correspondência" em Ana C. O que no texto de abertura da Correspondência Incompleta conduz o organizador Armando Freitas Filho a afirmar no "Jogo de cartas" que:

Era como se primeiro ela escrevesse para alguém e depois o que tinha endereço ou destino torna-se, através de uma estratégia dissimulatória, errante, sem referente claro, mensagem na garrafa, atirada ao oceano de todos para ser aberto por Ninguém ou por qualquer um, ao acaso. ${ }^{31}$

Estratégia dissimulatória que traiu a própria poeta, já que seu pedido à destinatária e também organizadora da edição, Heloísa Buarque de Hollanda, "PS: minhas cartas são confidenciais" 32 , foi evidentemente traído; já no "PS.1” da Correspondência completa o interdito é direcionado: "Não quero que T. leia nossa correspondência, por favor. Tenho paixão mas também tenho pudor!"33. A então organizadora, na sessão de depoimentos, colocará a questão da instabilidade dos papéis preestabelecidos de escritor $\mathrm{x}$ leitor, remetente $\mathrm{x}$ destinatário em Ana C.:

Não será a toa que a questão que sua escrita ainda hoje levanta é a questão do interlocutor, de seu destinatário. Para quem Ana escrevia? Quem escrevia, quando Ana C. escrevia? $^{34}$

Em ensaio intitulado "O tu na literatura”, Leminski defenderá que no processo de inovação da linguagem qualquer um dos fatores pode ser modificado: o emissor, o receptor, o suporte físico da mensagem, o código da mensagem ${ }^{35}$. Desdobrando o que seriam "Ficções no polo emissor”, afirma: "posso fingir que este eu que surge nos verbos da minha mensagem seja outra pessoa"36 e exemplifica com o poema"150.000.000" de Maiakovski, no qual o soviético constrói um eu-poético que torna-se os próprios 150.000.000 habitantes da Rússia. Leminski rebate então a crítica de Trotski em "Literatura e Revo- 
lução", que acertaria no alvo que não viu: "[Trotski] denuncia o artifício como sendo aquilo que é: apenas um faz-de-conta" ${ }^{37}$. Desdobrando ainda o ensaio para as "Ficções no polo receptor", indaga então: "quem é o invisível alvo do texto de criação?”38 Afirma então que há um público efetivo e um público simulado, sendo este último parte do próprio processo criativo do escritor/poeta. Estamos novamente diante do leitor e do "outro", sobre o qual Ana C. afirma: "você não sabe direito, e é má-fé dizer que sabe" ${ }^{39}$. Sendo assim, para Leminski: "o escritor é impossibilitado, na prática, de ler e atingir o público que deseja. Resta a solução melancólica de simular seu público" ${ }^{40}$. A “má-fé" que Ana C. cita é exemplificada na figura de Jorge Amado, que teria seu interlocutor definido como o "povo" e Leminski evidencia as consequências práticas da melancolia do escritor: "Assim, vemos milhares de poemas dirigidos ao povo que o povo não lerá nem deles tomará conhecimento: cartas que não chegam, tomam rumo ignorado [...]"41.

Alberto Moreiras pensando as Otobiographies de Derrida e analisando uma resposta de Derrida no debate que seguiu sua intervenção - na qual este defendia que a assinatura de Nietzsche só toma lugar depois de escrita, quando o outro forma a aliança, sendo na verdade justamente o outro que garante o pacto da assinatura - defenderá que: "não há que se apressar em entender neste outro um outro meramente empírico. $\mathrm{O}$ outro é de natureza estrutural [... " ${ }^{42}$. Sendo assim, a demanda do outro, nas poéticas de Ana C. e Leminski, não significa, entretanto, a ideia de um público definido a priori. Aqui, o leitor é estrutural e faz parte do próprio texto. Quem demanda e solicita o leitor é o próprio texto, que depende do leitor mas não é determinado por algum conjunto da sociedade. $\mathrm{O}$ engajamento do escritor se arma na forma que articula seu próprio texto e suas interlocuções que reverberam a partir da cena. Uma nota de rodapé na página 62 do próprio poeta em seu livro Distraídos Venceremos é emblemática: “(esse poema já foi musicado duas vezes. Uma por Moraes Moreira, outra por Itamar Assumpção. Que tal você??)"43.

Em Neo-retórica e desconstrução, David Wellbery estabelece um panorama histórico em que evidencia a derrocada da Retórica enquanto disciplina mestra da política e da estética, sendo o Iluminismo e o Romantismo, respectivamente nas determinadas áreas mencionadas acima, os movimentos que se impuseram com um novo projeto de domínio do discurso. Entretanto, como em todo processo histórico, há cumplicidade em tal ruptura - "aufhebung: o conceito hegeliano que quer dizer / ANIQUILAR \& MANTER" ${ }^{4}$, resgata Leminski em carta para Régis Bonvicino. A fim de evidenciar tal cumplicidade, é a partir do caso emblemático de Galileu Galilei que Wellbery demonstrará de que modo um dos expoentes da ciência mo-
37. Ibidem, p. 128.

38. Ibidem, p. 129.

39. Ana Cristina Cesar, apud.

SISCAR, Marcos. Ana Cristina

Cesar, 2012, p. 41.

40. LEMINSKI, Paulo. Ensaios e anseios crípticos, 2011, p. 130.

41. Ibidem. Grifos meus.

42. MOREIRAS, Alberto.

Autografía: pensador firmado

(Nietzsche y Derrida). In:

Suplementos Anthropos, 1991,

p. 132. Trecho com minha tradução.

43.LEMINSKI, Paulo.

Distraídos venceremos, 2002,

p. 62. O dêitico pessoal

"você" é a primeira palavra

de pelo menos sete poemas de

Leminski, segundo consta no

"indice de primeiros versos" do Toda poesia.

44. LEMINSKI, Paulo. Carta 2.

In: Envie meu dicionário, 1999, p. 36. 
45. Galileo Galilei, apud. WELLBERY, David E.

Retoricidade: sobre o retorno modernista da retórica, 1998, p. 16.

46. WELBERRY, David E., Retoricidade: sobre o retorno modernista da retórica, 1998, p. 17.

47.Ibidem, p. 15.

48. Ibidem.

49. LEMINSKI, Paulo. Carta 55. In: Envie meu dicionário, 1999, p. 156. Grifo meu. derna não estava imune a performances de retórica. Segundo Wellbery, "o modernismo é uma época, não de retórica, mas de retoricidade." $\mathrm{E}$ a retoricidade é marcada por um deslocamento da esfera oral da oratória para o texto escrito. Ou seja, uma saída da demonstração de técnicas específicas para a demonstração de uma posição marcada pelo próprio sujeito, prática consagrada no ensaísmo. No caso de Galileu, Wellbery ilustra como no prefácio/dedicatória de sua obra Mensageiro das estrelas, Galileu agraciava seu patrono, Cosimo II De Medici:

[...] a clemência, a bondade do coração, a gentileza nas maneiras, o esplendor do sangue real, a nobreza nos negócios públicos e a excelência da autoridade e da lei fixaram residência em Vossa Alteza. E quem, pergunto uma vez mais, não sabe que todas essas virtudes emanam da estrela benigna de Júpiter, a seguinte, depois de Deus, fonte de todas as coisas boas. $[. . .]^{45}$

Na dedicatória Galileu assume uma posição nítida dentro de uma cadeia hierárquica e articula uma "cadeia de imagens" para glorificar seu patrono à altura das estrelas. Já no texto propriamente científico, destaca Wellbery, desaparece a "sobrecodificação do discurso" e surge então um novo modo de endereçamento:

A estrela mais a leste estava a sete minutos de Júpiter e trinta segundos de sua vizinha; a do oeste, estava a dois minutos de distância da de Júpiter. As estrelas do final eram muito brilhantes e eram maiores que as do meio, que pareciam muito pequenas $[. . .]^{46}$

E a partir deste episódio, Wellbery caracteriza a retórica como "a arte da tomada de posição no discurso. [...] Os oradores são apresentadores que se adaptam às ocasiões com o fim de ganhar ou manter posição" ${ }^{47}$. Sinalizado já o deslocamento do campo oral para o da escrita, a tomada estratégica de posição continua acontecendo na modernidade e sua retoricidade. O que não implica uma retomada da Retórica clássica, mas a constatação de que os discursos são construídos não a partir de uma objetividade padrão, segundo leitura de Wellbery acerca do texto "Sobre verdade e mentira num sentido extramoral" de F. Nietzsche, mas sim adequados e tensionados estrategicamente diante de conflitos entre forças concorrentes. Assim, Galileu Galilei enquanto representante do espírito científico, também "operava como hábil estrategista dentro de uma complexa rede de alianças políticas e religiosas." ${ }^{48}$ Paulo Leminski em carta a Régis Bonvicino, ao relatar suas aspirações diante da MPB, caracterizou o projeto como "operação mass-mídia"49 e, em outra carta a Bonvicino, Leminski se posiciona evidenciando uma tática de guerrilha do discurso: 
$[\ldots]$

com meia dúzia de slogans verdadeiros na cabeça

cerco a montanha

ponho cerco às fortificações

tomo a posição e a defendo $[. . .]^{50}$

Em 1985, Leminski participou como conferencista em um dos ciclos de debate que o Núcleo de Estudos e Pesquisas da FUNARTE vinha realizando, este então dedicado a discutir “Os sentidos da paixão”. Como convidado, Leminski proferiu a palestra "Poesia: paixão da linguagem", na qual desenvolveu a ideia de que a relação que o poeta estabelece com a linguagem e sua língua é uma relação de amor: inicialmente masoquista (quando sofre os golpes de sua sintaxe e léxico) e posteriormente sádica (quando o poeta devolve - com o poema experimental - os golpes que sofreu da língua). Como é recorrente em seus textos, discutirá em determinado momento a questão da mercantilização da arte e o papel de resistência que a poesia cumpre nesse processo. Neste caso, pelo seguinte motivo:

Poesia é um ato de amor entre o poeta e a linguagem. E esse é um território como se fosse assim uma reserva ecológica do mercado em que vivemos que resiste ao fato de se transformar em mercadoria. [...] Pode-se comprar sexo de outra pessoa, mas o amor a gente sabe que é o último reduto que resiste à transformação em mercadoria. Então, eu acho que realmente a paixão do poeta pela linguagem, da linguagem pelo poeta, é coisa que tem amplas implicações sociológicas, históricas, transcendentais... Que vocês acham? Passei no teste?51

Então a palestra abre-se para o debate, em mais um gesto leminskiano de interpelação do outro - semelhante ao de Ana C. na sua comunicação citada no início deste texto -, momento em que a questão do amor do poeta e a linguagem será retomada por uma pergunta da plateia. Entretanto, o que gostaria de evidenciar é uma outra fundamentação de Leminski para a questão da poesia resistir à mercantilização. No seu ensaio “Arte inútil, arte livre?”, Leminski estabelece um panorama histórico do processo de "autonomização" do campo artístico. Assim, atribui as grandes funções que a arte desempenhou em determinados momentos históricos. Na Idade Média, delectare e docere - agradar e instruir, já no Renascimento Italiano, somente o delectare, mas nas contrarreformas de Lutero e Calvino existiu uma persistência do motivo utilitarista da arte. Leminski aponta então o que seria o surgimento do industrianato no lugar do artesanato, com o fim do Antigo Regime e a consolidação da Revolução Francesa. Nesse processo estaria o embrião das concepções da "arte pela arte”, o surgimento da arte moderna e então: "ao ouvir falar em arte moderna, o
50. Idem. Carta 9, In: Envie meu dicionário, 1999, p. 50.

51. Idem. Poesia: a paixão da linguagem, 2009, p.322. Grifo meu. 
52. LEMINSKI, Paulo. Arte inútil, arte livre?. In: Ensaios crípticos, 2011, p. 45.

53. Ibidem, p. 46.

54. Idem. Sem eu, sem tu, nem ele, p. 106.

55. Idem. O autor, essa ficção, p. 123. burguês puxa o talão de cheques" ${ }^{52}$. Neste processo de mercantilização, Leminski afirma que determinada área da arte - a literatura e especialmente a poesia - resistiu com especial vigor a este processo, devido a um motivo que, segundo o poeta, não era de admirar:

Uma palavra, toda palavra pertence a um idioma particular, historicamente determinado no espaço e no tempo, o mais pesado lastro coletivo que o homem pode carregar. Falar basco na Espanha ou gaélico na Irlanda é um gesto, em si, político (as nações deveriam coincidir com o espaço de uma língua ou dialeto). Cada palavra tem sua história, sua biografia, sua etimologia. Seu uso deflagra uma constelação de sub-significados e sentidos que, em cada idioma particular, tem certo desenho próprio e intransferível. A palavra é, essencialmente, política. Portanto, ética. Daí, talvez, a dificuldade de transformar a literatura, a poesia, em mercadoria. ${ }^{53}$

O que na palestra fora uma relação de amor entre o poeta e a linguagem, no ensaio tornou-se, talvez, a relação histórica e política que a própria palavra da poesia carrega. Apesar da hesitação, o motivo é bastante diverso. Mas como o próprio poeta afirmara na conferência, a paixão do poeta pela linguagem tem “amplas implicações sociológicas, históricas [...]”. Ou seja, não se trata de identificar aqui uma contradição ou incoerência no pensamento crítico do poeta, mas de perceber como se constroem suas performances autorais ao longo do seu percurso. Afinal, "o primeiro personagem que um escritor cria é ele mesmo" ${ }^{54}$ e, ainda, em "O autor, essa ficção", é o principal personagem que a ficção inventou ${ }^{55}$.

No ensaio "Poesia no receptor", Leminski arma uma cena ao relembrar frases célebres de grandes figuras históricas: "Quem não tiver pecado, atire a primeira pedra" (Jesus); "L'État, c'est moi” (Luís XIV) e "Quando ouço falar em cultura, levo a mão ao meu revólver” (Goebbels), e em seguida afirma: "Conferencista que se preza (e preza sua arte) tem sempre pronta pelo menos meia dúzia de frases de impacto garantido para sacar no caso de uma conflagração nuclear mais séria [...]", e então, reservando seu lugar distante diante dos "ilustres predecessores", elege sua própria frase de efeito: "Poesia é feita para poetas". Como bom publicitário, guarda a frase de impacto sabendo que esta tem uma função que é sair dela mesma em busca de outro lugar - cumprir um trajeto: "Quando, em minhas palestras, chego nesse ponto, instala-se o tumulto, que deixo desenvolver-se um pouco para valorizar a frase que vem a seguir.” E então finaliza o seu texto-simulacro de conferência:

- Um momento. Poeta não é só quem faz poesia. É também quem tem sensibilidade para entender e curtir poesia. 
Mesmo quem nunca tenha arriscado um verso. [...] Nesse auge, a multidão prorrompe em aplausos e me carrega em triunfo até o bar mais próximo, onde beberemos à saúde de todos os poetas-produtores e todos os poetas-receptores do mundo. ${ }^{56}$

Assim sendo, a forma com que Leminski se dirige ao outro é notadamente pouco ortodoxa. Quando teve a oportunidade de conhecer pessoalmente Antonio Risério, sendo o primeiro atrito até então aquela carta citada anteriormente, minutos depois de apresentados, Leminski abraça Risério e desfere-lhe um golpe de judô que leva o outro poeta ao chão; e assim justificaria o gesto inusitado: "Não sejamos formais um com o outro..." ${ }^{77}$.

Em Até segunda ordem não me risque nada (2007), Flora Süssekind constrói uma leitura da poética de Ana C. a partir de seus cadernos e rascunhos. É através das próprias leituras que Ana C. fazia, suas anotações e principalmente traduções, que Süssekind defenderá que a poesia-em-vozes de Ana C. é na verdade uma conquista a partir dos processos de elaboração da poeta e do seu próprio projeto poético. Esta conquista das vozes, entretanto, não se dá a partir de uma assimilação direta de certo "coloquialismo", ou "paixão prosaica”, impregnados na poesia da época.

É importante destacar a maneira com que tanto Ana C. quanto Leminski registraram em poema o conflito com outras vozes - estabelecendo uma relação tensa de aproximação/afastamento - e com o seu próprio tempo, marcando uma necessidade de não-pertencer simultaneamente quando se faz parte. Ou seja, assumem o gesto agambeniano de ser contemporâneo. Ana C. com "A lei do grupo":

todos os meus amigos estão fazendo poemas-bobagens ou poemas-minutos ${ }^{58}$

E Paulo Leminski com o “poesia: 1970”:

$$
\begin{aligned}
& \text { tudo o que eu faço } \\
& \text { alguém em mim que eu desprezo } \\
& \text { sempre acha o máximo } \\
& \text { mal rabisco, } \\
& \text { não dá mais para mudar nada } \\
& \text { já é um clássico }
\end{aligned}
$$

Rejeição e pertencimento inevitável ${ }^{60}$ : Ana C. se distancia dos "poemas-bobagens" dos amigos fazendo seu próprio "poema-minuto", Leminski cinde o sujeito poético desprezando o
56. Idem. Poesia no receptor, p. 132.

57. Relato encontrado no capítulo "Um capítulo à parte" na biografia de Toninho Vaz.

58. Ana Cristina Cesar, apud. SÜSSEKIND, Flora. Até segunda ordem não me risque nada, 2007, p. 18.

59. LEMINSKI, Paulo. Toda poesia, 2013, p. 230.

60. Nas indicações de leitura do livrinho irônico de Glauco Mattoso O que é poesia marginal (coleção Primeiros passos), aprecem dois textos críticos de Leminski (nenhum trata da "poesia marginal”); Heloísa Buarque de Hollanda, nos depoimentos da Correspondência incompleta, afirma que Ana C. é uma "poeta marginal especial"; e ainda o livro em que os dois figuram juntos, Poesia marginal da coleção "Para gostar de ler" (presente na lista de leitura obrigatória do vestibular da UFSC de 2013). 
61. SÜSSEKIND, Flora, Até segunda ordem não me risque nada, 2007, p. 11. Em uma carta a Régis, Leminski se despede: "duas joias do populário q recolhi para você, da bocadopovo: - quem come pedra, sabe o cu que tem/- quem já tá no inferno, não custa dar um abraço no diabo/ Tchau, gatão! Leminski (1999, p.61). Nas "Notas às cartas", Tarso M. de Melo registra: "Leminski, estudioso e colecionador de provérbios e invenções verbais populares, enviou certa vez a Régis

Bonvicino, com anotações de próprio punho, o Prólogo da Comédia Eufrosina - uma coleção de provérbios - de João da Espera de Deus (séc. XIX)" (MELO, Tarso de. Apud: LEMINSKI, Paulo, 1999, p.184).

62. SÜSSEKIND, Flora, Até segunda ordem não me risque nada, 2007, p. 41.

63. Ibidem, p. 18.

64. Ibidem, p. 20.

65. Ibidem, p. 22.

66.LEMINSKI, Paulo.

Vanguarda do ficar. In: Anseios crípticos, 2011, p. 121. próprio poema que faz. Süssekind então lerá a poesia de Ana C. e sua relação com o real-experiência como atividade de "life studies" ${ }^{\prime \prime}$, mas, nesse sentido:

Isso não significou, como se sabe, no caso de Ana Cristina Cesar, a opção por textos-retratos ou pelo puro e simples diário de uma "vida real" ou uma geração. Percebida "a lei do grupo", Ana Cristina, ainda em meados dos anos 70, ficcionalizaria correspondências e jornais íntimos, como nas "Três cartas a Navarro", assinadas por "R", guardadas na pasta rosa de "inacabados, soltos ou rejeitados", nas quais brinca diretamente com o que chama de "obscurantismo biografílico". ${ }^{62}$

Além dos "life studies" como forma de trabalhar a construção de uma poesia-em-vozes, Süssekind atenta para os exercícios e trabalhos de tradução que Ana C. desenvolvia como espaço de reflexão poética, demonstrando que o "coloquialismo" de Ana C. é na verdade fruto de um "exercício de prosaização" ${ }^{63}$, como na leitura que faz da tradução de José Paulo Paes do poema "Os Passos” de Konstantinos Kaváfis, substituindo "Enírias" por "Fúrias" (vide exemplo evidenciado por Flora), que afirma ainda ser também no trabalho de tradução o espaço onde se exercita o que a própria Ana C. reivindicara como "delimitar o próprio território". ${ }^{64}$ Os exercícios de Ana C. ainda são vários, passando por releituras e traduções de Manuel Bandeira, Fernando Pessoa, Drummond, Elizabeth Bishop, T. S. Eliot, Marianne Moore, Havelock Ellis, e ainda o seu objeto de mestrado de 1980 na Essex, o conto Bliss de Katherine Mansfield. Leminski com suas traduções e reflexões nos prefácios ou posfácios dos livros que traduziu de Beckett, John Lennon, Yukio Mishima, Alfred Jarry, Petrônio, Ferlinguetti, Joyce, John Fante e Whitman. Apesar das obrigações profissionais de cada um, de Ana C. com a universidade e de Leminski com a editora (Brasiliense), o trabalho da tradução em ambos é parte do exercício crítico do seu próprio fazer poético. Ou seja, a tradução é interessada ${ }^{65}$, como afirmara Flora Süssekind.

Em 1974 a banda inglesa Rolling Stones lançava o álbum It's only rock'n'roll com música homônima - o título + (but I like it) - que se tornou um single do disco. Banda elogiada por Leminski por justamente fazer parte do grupo daqueles que não mudam. "Que bom. Não muda, João!”"66, em referência a João Cabral de Melo Neto. Quem mudou então foi o próprio Leminski, em poema do livro Não fosse isso/ e era menos/ não fosse tanto/ e era quase (1981), incluído na então primeira coletânea de edição nacional de seus poemas, Caprichos \& Relaxos(1983), fazendo parte da coleção "Cantadas Literárias”: 
it' s only life

but i like it

let's go

baby

this is life

$$
\text { let's go }
$$

it is not

$$
\text { rock and roll }{ }^{67}
$$

Em 1978 Leminski escreve uma longa carta a Bonvicino, comparada ao restante do corpus publicado, dedicada exclusivamente a demolir criticamente o então lançado LP de Walter Franco, Respire Fundo. São mais de quatro páginas que incluem críticas do tipo:

aquele misticismo decadente harehare/ aquela chinoiserie orientalóide/ aquele clima frufru de quem está em algum lugar/ e não pertence a povo algum/ [...] com sua cara de riquinho/ filho de papai q sempre teve tudo/ "sentir o céu se transformar num lindo blue"/ ora francamente/ [...] UTOPIA SIM! HINDUISMO NÃO! ${ }^{68}$

O rigor da crítica não é aleatório, pois até então Leminski tinha grande admiração pelo trabalho de Walter Franco, mas a crise foi grande a ponto do músico perder o posto para o cineasta Glauber Rocha em poema publicado no Polonaises (1981), também incluído na coletânea de 1983:

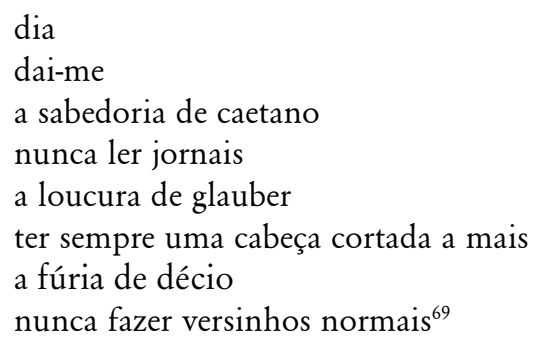

Em outra carta a Bonvicino, um ano depois, Leminski enviara este mesmo/outro poema com "walter franco" ainda no lugar de glauber ${ }^{70}$. Transição que a edição da correspondência deixa clara ao colocar o poema logo em seguida na ordem das cartas. Em 1988, sabendo ou não da carta, Walter Franco cede espaço de seu palco em São Paulo, onde tocava também com Cid de Campos, para Leminski subir e dividirem o poema musicado "Pedra Polida"71, momento em que, segundo Toninho Vaz, Leminski foi "calorosamente aplaudido".

Carta publicada pela primeira vez em 1992 (Uma carta uma brasa através), nova edição em 1999 (Envie meu dicionário) e em 2011 Walter Franco sobe ao palco novamente, dessa vez em evento comemorativo do aniversário da cidade de São Paulo:
67. LEMINSKI, Paulo. Toda poesia, 2013, p. 110.

68. LEMINSKI, Paulo. Carta 34. In: Envie meu dicionário, 1999, p. 90.

69. LEMINSKI, Paulo. Toda poesia, 2013, p. 78.

70. LEMINSKI, Paulo. Carta 35. In: Envie meu dicionário, 2007, p. 94.

71. VAZ, Toninho Paulo

Leminski: o bandido que sabia latim, 2001, p. 290. 
72. FRANCO, Walter. It's on life, but i like it. Performance disponível no site Youtube: www.youtube.com/ watch? $=\mathrm{vQzFkQfzOZQ}$. Transcrição minha.

73. Ibidem. It's on life, but i like it: www.youtube.com/ watch? $\mathrm{v}=\mathrm{WWu} 4 \mathrm{hjSPjPI}$

74. DERRIDA, Jacques, O cartão-postal. De Sócrates a Freud e além, 2007.

75. CESAR, Ana Cristina. $A$ teus pés, 2002, p. 56.

76. BANDEIRA, Manuel. Apud: GALVÃO, Walnice Nogueira. In: Teresa Revista de Literatura Brasileira. Departamento de Letras Clássicas e Vernáculas, Faculdade de Filosofia, Letras e Ciências Humanas. Universidade de São Paulo, $n^{\text {os }}$ 8-9. Ed. 34, 2008. p.24.
O Paulo Leminski é... o máximo. Eu digo “é” porque continua sendo. Ele fez uma verdadeira revolução na literatura e deixou obras-primas assim: este poema fala da vida, "é somente vida, mas eu gosto. ${ }^{72}$

E irrompe cantando o poema "Its only life". Em outra performance de Walter Franco, no evento "Balada Literária"73 com Augusto de Campos na plateia e palco - antes de musicar o poema, declama o auto-retrato "cachorro louco" de Leminski e relembra com Augusto de Campos o episódio de 1988 - "ele subiu no palco e dançou conosco". Afirma então ter refletido ao encontrar o poema: "mas isso é uma resposta a essa coisa do rock'n'rolP'. A performance que se segue é sem dúvida uma resposta à carta de 78 de Leminski, carta atrasada - posta restante $^{74}$ - doce e azeda $a^{75}$ - misturando fúria e loucura, buscando fazer renascer a cabeça cortada do poema antigo.

$$
* * *
$$

$\mathrm{Na}$ resposta à carta de Heidegger sobre o humanismo (Regras para o parque humano), o filósofo Peter Sloterdijk define a história do humanismo, ou até mesmo da filosofia ocidental, como uma longa troca de cartas entre amigos. Sendo assim, como na carta para Mário de Andrade, na qual Manuel Bandeira afirmara ser a correspondência dos modernistas brasileiros um romance ${ }^{76}$, a história dos poetas brasileiros contemporâneos - no sentido cronológico enquanto "pós-modernos" - mostra-se aberta ou incompleta diante da própria impossibilidade, enquanto romance, que Paulo Leminski realizou em Agora é que são elas. 


\section{Referências}

ARFUCH, Leonor. O espaço biográfico: dilemas da subjetividade contemporânea. Trad. Paloma Vidal. Rio de Janeiro: EdUERJ, 2010. Original: Buenos Aires, 2002.

CESAR, Ana Cristina. A teus pés. $2^{\circ}$ ed. São Paulo: Editora Ática, 2002.

Correspondência Incompleta. Ana C. [organização Armando Freitas Filho e Heloísa Buarque de Hollanda]. Rio de Janeiro: Aeroplano, 1999.

CLARK, Lygia; OITICICA, Helio. Cartas. 1964-1975. Org. Luciano de Figueiredo. Rio de Janeiro: Editora UFRJ, 1996.

DERRIDA, Jacques. O cartão-postal. De Sócrates a Freud e além. Trad. Ana Valéria Lessa e Simone Perelson. Rio de Janeiro: Civilização Brasileira, 2007.

FOUCAULT, Michel. A escrita de si. In: O que é um autor? Lisboa: Passagens, 1992.

HEER, Liliana. La Correspondencia: Una Voz en el Camino. In: Cartas em la Realidad y la Ficción. Buenos Aires: Desde la Gente Ediciones, Instituto Movilizador de Fondos Cooperativos, 1995.

LACAN, Jacques. Escritos. Trad. Vera Ribeiro. Rio de Janeiro: Jorge Zahar Ed., 1998. . Lituratera. Trad. Luiz de Souza Dantas Forbes.

Disponível em: <http://www.psicanaliselacaniana.com/ estudos/documents/LiturateracomlogoIPLA.pdf $>$. Último acesso em: 18/06/2013.

LEMINSKI, Paulo. Agora é que são elas. São Paulo: Iluminuras, 2011.

_. Ensaios e anseios crípticos. Campinas, SP: Editora da Unicamp, 2011.

_-_. Distraídos venceremos. $5^{\circ}$ ed. São Paulo: Brasiliense, 2002.

; BONVICINO, Régis. Envie meu dicionário: cartas e alguma crítica. Paulo Leminski e Régis Bonvicino, organização de Régis Bonvicino com a colaboração de Tarso M. de Melo. São Paulo: Editora 34, 1992 (1ํo edição). 1999 (2º edição - 1ํo reimpressão 2007). 
Poesia: a paixão da linguagem. In: NOVAES, Adauto (org.). Os sentidos da paixão. São Paulo: Companhia das Letras, 2009.

___. Toda poesia. $1^{\circ}$ ed. São Paulo: Companhia das Letras, 2013.

Uma carta uma brasa através. Cartas a Régis Bonvicino (1976-1981). Seleção, introdução e notas Régis Bonvicino. São Paulo: Iluminuras, 1992.

LUDMER, Josefina. La novia (carta) robada (a Faulkner). Disponível em: www.cartas.org.ar/lecturas/lec-lud-lan.html. Acesso em 12/2/2013.

MOREIRAS, Alberto. Autografía: pensador firmado (Nietzsche y Derrida). In: Suplementos Anthropos. Barcelona, 1991.

MORICONI, Italo. Ana Cristina Cesar: o sangue de uma poeta. Rio de Janeiro: Relume-Dumará, 1996.

ROCHA, Glauber. Cartas ao mundo. Org. Ivana Bentes. São Paulo: Companhia das Letras, 1997.

SISCAR, Marcos. "Apresentação", In: CESAR, Ana Cristina. Ana Cristina Cesar por Marcos Siscar. Col. Ciranda da Poesia. Ed. UERJ: Rio de Janeiro, 2012.

SLOTERDJIK, Peter. Regras para o parque humano: uma resposta à carta de Heidegger sobre o humanismo. Trad. José Oscar de Almeida Marques. São Paulo: Estação Liberdade, 2000.

SÜSSEKIND, Flora. Até segunda ordem não me risque nada: os cadernos, rascunhos, e a poesia em vozes de Ana Cristina Cesar. $2^{\circ}$ ed. Rio de Janeiro: 7Letras, 2007.

VAZ, Toninho. Paulo Leminski: o bandido que sabia latim. Rio de Janeiro: Record, 2001.

REVISTA TERESA DE LITERATURA BRASILEIRA.

Departamento de Letras Clássicas e Vernáculas, Faculdade de Filosofia, Letras e Ciências Humanas. Universidade de São Paulo, $n^{\text {os }} 8-9$. Ed. 34, 2008.

WELLBERY, David E. Retoricidade: sobre o retorno modernista da retórica. Neo-retórica e desconstrução. Trad. Angela Melim. Rio de Janeiro: EdUERJ, 1998. 